\title{
Additive Testing for Improved Sulfur Retention: Preliminary Report
}

J. W. Amoroso

K. M. Fox

September 2011

Savannah River National Laboratory Savannah River Nuclear Solutions, LLC Aiken, SC 29808

Prepared for the U.S. Department of Energy under contract number DE-AC09-08SR22470.

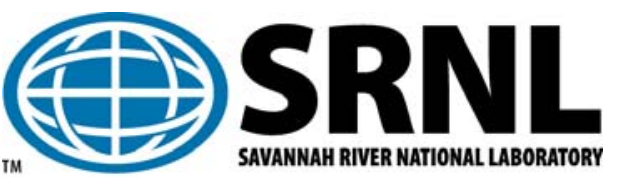


SRNL-STI-2011-00524

Revision 0

\section{DISCLAIMER}

This work was prepared under an agreement with and funded by the U.S. Government. Neither the U.S. Government or its employees, nor any of its contractors, subcontractors or their employees, makes any express or implied:

1. warranty or assumes any legal liability for the accuracy, completeness, or for the use or results of such use of any information, product, or process disclosed; or

2. representation that such use or results of such use would not infringe privately owned rights; or

3. endorsement or recommendation of any specifically identified commercial product, process, or service.

Any views and opinions of authors expressed in this work do not necessarily state or reflect those of the United States Government, or its contractors, or subcontractors.

\section{Printed in the United States of America \\ Prepared for \\ U.S. Department of Energy}


Keywords: DWPF, glass, sulfur, solubility

Retention: Permanent

\section{Additive Testing for Improved Sulfur Retention: Preliminary Report}

J. W. Amoroso

K. M. Fox

September 2011

Savannah River National Laboratory

Savannah River Nuclear Solutions, LLC Aiken, SC 29808

Prepared for the U.S. Department of Energy under contract number DE-AC09-08SR22470.

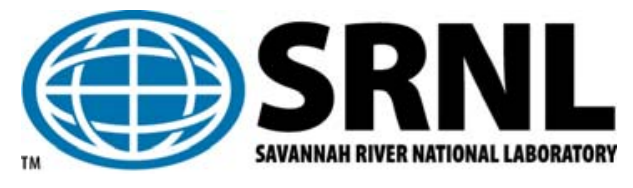




\section{REVIEWS AND APPROVALS}

AUTHORS:

J. W. Amoroso, Process Technology Programs

Date

K. M. Fox, Process Technology Programs

Date

TECHNICAL REVIEW:

F. C. Johnson, Process Technology Programs

Date

APPROVAL:

C. C. Herman, Manager

Date

Process Technology Programs 


\section{EXECUTIVE SUMMARY}

The Savannah River National Laboratory is collaborating with Alfred University to evaluate the potential for additives in borosilicate glass to improve sulfur retention. This preliminary report provides further background on the incorporation of sulfur in glass and outlines the experiments that are being performed by the collaborators. A simulated waste glass composition has been selected for the experimental studies. The first phase of experimental work will evaluate the impacts of $\mathrm{BaO}, \mathrm{PbO}$, and $\mathrm{V}_{2} \mathrm{O}_{5}$ at concentrations of 1.0, 2.0, and $5.0 \mathrm{wt} \%$ on sulfate retention in simulated high level waste borosilicate glass. The second phase of experimental work will evaluate the effects of time at the melt temperature on sulfur retention. The resulting samples will be characterized to determine the amount of sulfur remaining as well as to identify the formation of any crystalline phases. The results will be used to guide the future selection of frits and glass forming chemicals in vitrifying Department of Energy wastes containing high sulfur concentrations. 


\section{TABLE OF CONTENTS}

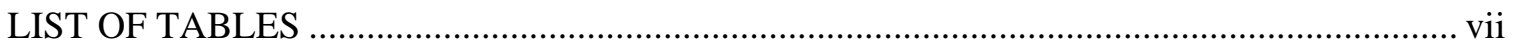

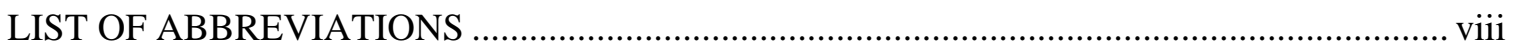

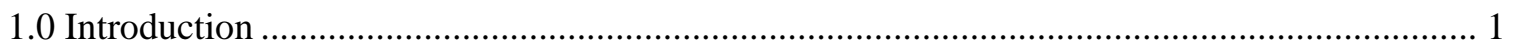

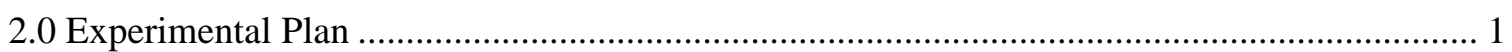

2.1 Simulated Waste Glass Composition ............................................................................... 1

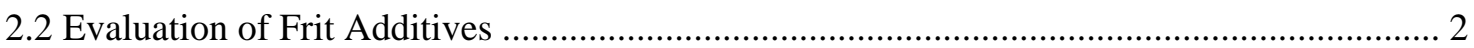

2.3 Evaluation of Sulfur Retention Over Time …................................................................ 2

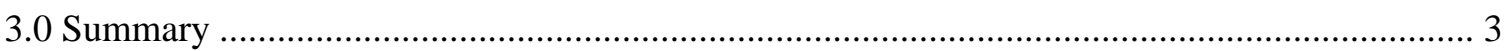


SRNL-STI-2011-00524

Revision 0

\section{LIST OF TABLES}

Table 2-1. Simulated Waste Glass Composition for Sulfate Retention Studies............................. 2

Table 2-2. Outline of Frit Additive Experiments. ........................................................................ 2 


\section{LIST OF ABBREVIATIONS}

$\begin{array}{ll}\text { AU } & \text { Alfred University } \\ \text { DOE } & \text { U.S. Department of Energy } \\ \text { DWPF } & \text { Defense Waste Processing Facility } \\ \text { HLW } & \text { High Level Waste } \\ \text { EM } & \text { Environmental Management } \\ \text { ICP-AES } & \text { Inductively Coupled Plasma - Atomic Emission Spectroscopy } \\ \text { SB6 } & \text { Sludge Batch 6 } \\ \text { SRNL } & \text { Savannah River National Laboratory } \\ \text { SRS } & \text { Savannah River Site } \\ \text { TDD } & \text { Technology Development and Deployment } \\ \text { XRD } & \text { X-ray Diffraction }\end{array}$


SRNL-STI-2011-00524

Revision 0

\subsection{Introduction}

Sulfur has a low solubility in borosilicate glasses. This presents a significant challenge to the U.S. Department of Energy (DOE) immobilization campaigns for wastes with high sulfur concentrations since borosilicate glass is being used to vitrify high level radioactive waste (HLW) at the Savannah River Site (SRS) and is planned for use in vitrifying wastes at Hanford. A more thorough understanding of the incorporation of sulfur in the borosilicate glass network (and the issues that hinder its incorporation) could lead to improvements in sulfur retention, allowing for a higher level of waste loading in the glass.

The Savannah River National Laboratory (SRNL) is collaborating with Alfred University (AU) to evaluate the potential for additives in the borosilicate glass frit or glass forming chemicals to improve sulfur retention. This preliminary report provides further background on the incorporation of sulfur in glass and outlines the experiments that will be performed by the collaborators. AU has completed a survey of relevant literature and provided recommendations for the experimental work. That document is included as Appendix A. The experimental work will be performed using simulated, non-radioactive glasses, with the intent of identifying modifications that can be made to the frit compositions recommended for future operation of the Defense Waste Processing Facility (DWPF) at SRS for improved sulfur retention.

This study is being performed for the DOE Office of Environmental Management (EM) under the Technology Development and Deployment (TDD) Program Task Plan WP-5.1.2. ${ }^{\mathrm{a}}$ This report is intended to fulfill deliverable WP-512-SRNL-03 as identified in the Task Plan. ${ }^{a}$ This work is controlled at SRNL by a Task Technical and Quality Assurance Plan. ${ }^{\mathrm{b}}$

\subsection{Experimental Plan}

\subsection{Simulated Waste Glass Composition}

SRNL provided the simulated waste glass composition shown in Table 2-1 to AU for use in the evaluation of frit additives for improved sulfate retention in glass. This simulated composition is based on a simplified projection of the composition of DWPF Sludge Batch 7b combined with SRNL Frit 418 at a waste loading of 36 wt \%.

\footnotetext{
a EM-30 Technology Development and Deployment (TDD) Program Task Plan, “Task Plan for WP-5 Task 5.1.2 Advanced Silicate Glass Development and Demonstration," WP5-5.1.2-FY2011 Revision 0, (2011).

b Amoroso, J. W., "Task Technical and Quality Assurance Plan for WP 5.1.2 - Advanced Silicate Glass Development and Demonstration,” U.S. Department of Energy Report SRNL-RP-2011-00731, Revision 0, Savannah River National Laboratory, Aiken, SC (2011).
} 
SRNL-STI-2011-00524

Revision 0

Table 2-1. Simulated Waste Glass Composition for Sulfate Retention Studies.

\begin{tabular}{||c|c|}
\hline Oxide & wt \% \\
\hline $\mathrm{Al}_{2} \mathrm{O}_{3}$ & 8.34 \\
\hline $\mathrm{B}_{2} \mathrm{O}_{3}$ & 5.36 \\
\hline $\mathrm{Ce}_{2} \mathrm{O}_{3}$ & 0.06 \\
\hline $\mathrm{Cr}_{2} \mathrm{O}_{3}$ & 0.04 \\
\hline $\mathrm{CuO}$ & 0.06 \\
\hline $\mathrm{Fe}_{2} \mathrm{O}_{3}$ & 10.30 \\
\hline $\mathrm{Li}_{2} \mathrm{O}$ & 5.36 \\
\hline $\mathrm{MgO}$ & 0.26 \\
\hline $\mathrm{MnO}$ & 2.21 \\
\hline $\mathrm{Na} 2 \mathrm{O}$ & 14.08 \\
\hline $\mathrm{NiO}$ & 1.75 \\
\hline $\mathrm{SiO}$ & 52.12 \\
\hline $\mathrm{ZrO}_{2}$ & 0.07 \\
\hline $\mathrm{Total}$ & 100.00 \\
\hline \hline
\end{tabular}

\subsection{Evaluation of Frit Additives}

Collaborators at $\mathrm{AU}$ have recommended that three frit additives, $\mathrm{BaO}, \mathrm{PbO}$, and $\mathrm{V}_{2} \mathrm{O}_{5}$, be evaluated for potential improvements in sulfate retention. Batching, melting, and some characterization of test glasses for this phase of the experimental work will be completed by AU. The recommended additives will be added in concentrations of 1.0, 2.0, and $5.0 \mathrm{wt} \%$. The concentrations of the frit components in the glass will be reduced proportionally to allow for the additives. The experiments and a naming convention for the glasses are provided in Table 2-2. Each of these glasses will be fabricated with targeted sulfate concentrations of 0.8 and $1.0 \mathrm{wt} \%$ in glass. Sulfur will be added to the batch using sodium sulfate. The amount of sodium carbonate added to the batch will be reduced to account for the sodium added as sodium sulfate. The concentrations of the sludge components in the glass will be reduced proportionally to allow for the addition of sulfur.

Table 2-2. Outline of Frit Additive Experiments.

\begin{tabular}{|l|c|c|c|}
\hline & $\mathbf{1 . 0}$ wt \% & $\mathbf{2 . 0} \mathbf{w t} \%$ & $\mathbf{5 . 0} \mathbf{w t} \%$ \\
\hline $\mathbf{B a O}$ & B1No & B2No & B5No \\
\hline $\mathbf{P b O}$ & P1No & P2No & P5No \\
\hline $\mathbf{V}_{\mathbf{2}} \mathbf{O}_{5}$ & V1No & V2No & V5No \\
\hline
\end{tabular}

A total of 18 glasses will be fabricated for this phase of the study. The glasses will be melted for one hour at $1150{ }^{\circ} \mathrm{C}$ in a covered platinum alloy crucible and then air quenched. Visual observations will be used to identify any sulfur gall layer on the surfaces of the melts after cooling. Samples of each glass will be sent to SRNL for dissolution and chemical analysis via Inductively Coupled Plasma - Atomic Emission Spectroscopy (ICP-AES). Other characterization at AU may include X-ray diffraction (XRD), microscopy, and other spectroscopic techniques, as required.

\subsection{Evaluation of Sulfur Retention Versus Time}

An additional set of experiments will be used to identify any impact of the additives on the retention of sulfur in the glass melt as a function of time. While typical laboratory experiments 
for sulfur retention involve melting simulated HLW glass for periods of 60 minutes, the residence time for actual HLW glass in the DWPF melter can be 20 hours or more. Therefore, an understanding of the retention of sulfur as a function of time at temperature is important in estimating the amount of sulfur that resides in the glass at the point of pouring. ${ }^{\text {a }}$

SRNL will provide a previously melted glass for this phase of the experiments, since a larger quantity of glass will be needed to support the test melts to be completed at AU. The glass will come from previous melter testing using simulated DWPF Sludge Batch 6 (SB6) material and Frit 418. SRNL will grind the glass and complete a chemical analysis prior to shipping the material to AU.

AU will add sodium sulfate to the ground glass to target a total sulfate concentration of $1.0 \mathrm{wt} \%$ in the glass. The most influential one or two additives from the first phase of the study (i.e., Section 2.2) will also be added at the optimal concentrations. The ground glass with additions will be re-melted in alumina crucibles at $1150{ }^{\circ} \mathrm{C}$ for periods of $1,2,4,8,24$, and 48 hours. The use of alumina crucibles will allow for sectioning with a diamond saw and evaluation of the sulfur concentration as a function of depth within the melt. Approximately $100 \mathrm{~g}$ of glass with additives will be melted for each time period. A select set of samples (to be determined at the end of the melting experiments) will be sent to SRNL for dissolution and chemical analysis via ICP-AES. Other characterization at AU may include XRD, microscopy, and other spectroscopic techniques, as required.

\subsection{Summary}

SRNL is collaborating with AU to evaluate the potential for additives in borosilicate glass to improve sulfur retention. The objective of the study is to extend knowledge of sulfur incorporation in relatively simple borosilicate glasses to the complex chemistry of HLW glass. This preliminary report provides further background on the incorporation of sulfur in glass and outlines the experiments that are being performed by the collaborators. A simulated waste glass composition has been selected for the experimental studies and sent to AU. The first phase of experimental work will evaluate the impacts of $\mathrm{BaO}, \mathrm{PbO}$, and $\mathrm{V}_{2} \mathrm{O}_{5}$ at concentrations of 1.0, 2.0, and $5.0 \mathrm{wt} \%$ on sulfate retention in simulated HLW borosilicate glass. The second phase of experimental work will evaluate the effects of time at the melt temperature on sulfur retention. The resulting samples will be characterized at AU and SRNL. The results will be used to guide future selection of frits and glass forming chemicals to be used in vitrifying DOE wastes containing elevated sulfur concentrations.

\footnotetext{
${ }^{a}$ Note that there are a number of other factors that will ultimately influence the retention of sulfur in an actual HLW melter, including cold cap coverage, feeding rates, plenum temperatures, atmosphere purge rates, convection in the melt pool, etc.
} 
SRNL-STI-2011-00524

Revision 0

Appendix A. 


\title{
SULFATE SOLUBILITY IN GLASSES
}

\author{
K. A. Sill
}

S. K. Sundaram

Kazuo Inamori School of Engineering

The New York State College of Ceramics at Alfred University

Alfred, NY 14802 


\section{TABLE OF CONTENTS}

1. INTRODUCTION 3

Page

2. GENERAL SULFUR BEHAVIOR 3

3. SULFATE THERMODYNAMICS 5

4. SULFUR DISOLUTION IN SILICATE GLASS SYSTEMS 5

a. Additives to Silicate glass systems to increase sulfur solubility ..............................5

5. SULFUR DISSOLUTION IN PHOSPHATE GLASS SYSTEMS6

a. Additives to Phosphate glass systems to increase sulfur solubility ...........................7

6. SULFUR DISSOLUTION IN BOROSILICATE GLASS SYSTEMS ............................8

a. Additives to Borosilicate glass systems to increase sulfur solubility .........................8

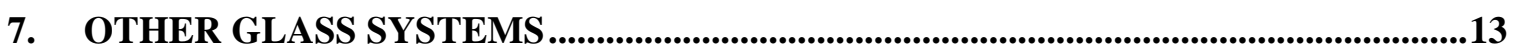

8. LABORATORY TESTS TO DETECT SULFUR LEVELS .......................................13

a. Raman Spectroscopy.................................................................................................13

b. Infrared Spectroscopy .....................................................................................................15

c. X-ray absorption - near edge spectroscopy (XANES) ...............................................15

d. Extended X - ray absorption - fine structure (EXAFS) ........................................15

e. Other tests ...............................................................................................................................15

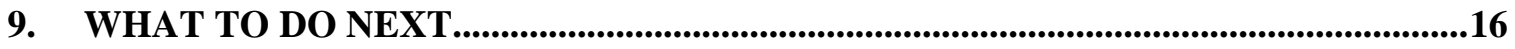

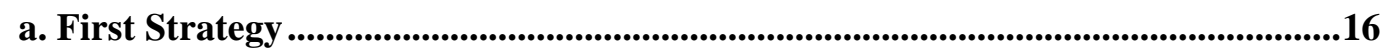

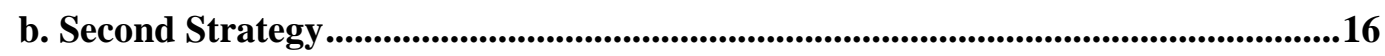

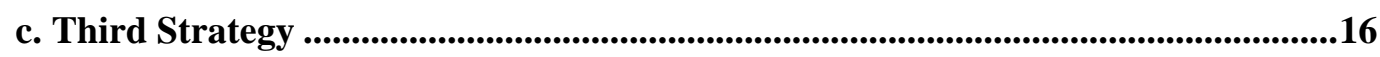

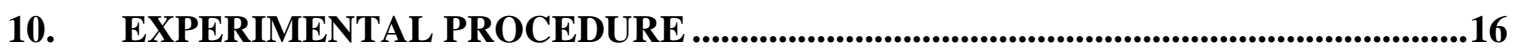

REFERENCES $\quad 17$ 


\section{INTRODUCTION}

Several nuclear wastes generated during the cold war and stored at various sites across the USA contain sulfates. The sulfate concentrations are generally high, making it difficult to incorporate into most glass systems, including borosilicate glasses. Low sulfate solubility in borosilicate glasses leads to many challenges, e.g., low melt viscosity, causing accelerated refractory corrosion at the melt line. A sulfate - rich layer that forms on top of the melt pool will result in volatility issues impacting the off - gas systems in the plant. The layer can also potentially short the electrodes of Joule - heated melters. Within this layer, radioactive cesium may partition, leading to its volatilization. Additionally, high - sulfate phases may precipitate on cooling, impacting the performance of the waste form. At the Savannah River Site (SRS) ${ }^{[1]}$, a sulfate concentration limit of 0.40 weight $\%$ (wt\%) of $\mathrm{SO}_{4}{ }^{2-}$ in high - level waste ( $\mathrm{HLW}$ ) glass was first set and then later increased to 0.60 wt\% for meeting the processing targets at the Defense Waste Processing Facility (DWPF), where borosilicate - based glass waste forms have been produced since 1996. There is a need to increase this limit to at least $1.0 \mathrm{wt} \%$ for meeting the future waste loading and production goals of the SRS. The present report examines various glass systems that can potentially be used to increase the sulfate solubility to meet these goals.

\section{GENERAL SULFUR BEHAVIOR}

Sulfur $\left(S^{0}\right)$ is commonly found in nature as crystals with other elements, in the valence states of $\mathrm{S}^{2-}$ (sulfide), $\mathrm{S}^{4+}$ (sulfite), or $\mathrm{S}^{6+}$ (sulfate). Thiosulfates are a sulfate bonded with three oxygens and a sulfide, commonly written as $\mathrm{S}_{2} \mathrm{O}_{3}$ but more comprehensibly written as $\mathrm{SO}_{3} \mathrm{~S}$. Sulfide functions as an anion bonding with positive cations, while sulfite and sulfate are most commonly bonded with oxygen. "Under reducing conditions, $\mathrm{S}$ behaves as an anion (or alloying element), forming bonds directly with metal cations, whereas under oxidizing conditions, it is a complexforming cation" [2]. This is relevant to nuclear waste treatment and maximizing sulfate solubility into glasses under reducing atmosphere in the melter used for vitrification.

Sulfur dissolution has been studied for many different glass systems due to its low ability to be incorporated into glass. Sulfate is present in nuclear waste most

usually due to the use of $\left[\mathrm{Fe}\left(\mathrm{NH}_{2} \mathrm{SO}_{3}\right)_{2}\right]$ as a reducing agent of $\mathrm{Pu}^{4+}$ to $\mathrm{Pu}^{3+[3-5]}$. The 
sulfate can also be a result of effluents of radioactive solutions, ion - exchanging resins, or of incineration before vitrification ${ }^{[6]}$.

The dissolution of sulfur into a glass system is complicated due to the many different factors that can influence the valence state of the sulfur in the glass ${ }^{[7]}$, and the multiple valence states that the sulfur can be in ${ }^{[3]}$, and the true sulfur solubility is not normally obtained as sulfur solubility in nuclear waste production glass is rarely in equilibrium ${ }^{[1,8]}$. Some factors that influence the valence state of the sulfur are temperature, reactivity, the partial pressure of sulfur-containing species over the glass melt, and the reduction-oxidation (redox) conditions of the melt ${ }^{[6]}$. In reducing conditions, the dissolution of sulfur is strongly dependent on Fe and less dependent on $f\left(\mathrm{O}_{2}\right)$, whereas in oxidizing conditions, it is strongly dependent on $f\left(\mathrm{O}_{2}\right)$. For the $\mathrm{Fe}-$ free compositions studied by Fleet et al., Ca becomes important in reduced melts ${ }^{[2,7]}$. In the case of nuclear wastes, $\mathrm{Fe}$ is generally present in some form in most of the wastes. According to Manara et al., the capacity of a vitreous matrix to incorporate sulfates depends on the compatibility between the crystallochemical parameters of the sulfate and those of the cations contained in the hostglass. These parameters are: the cation-oxygen binding energy; the Dietzel field strength $z_{c} / a^{2}$ where $z=$ charge of the cation and $a=$ (cation radius $+\mathrm{O}^{2-}$ radius); the strength of the bond $z_{c} / k$ where $k=$ coordination number of the cation; the size and polarization of the polyhedrons. According to this criterion, the cations present in a borosilicate glass containing vanadium $(V)$, phosphorus $(P)$, aluminum $(A)$ and zinc $(\mathrm{Zn})$, the glass may be distributed in the series: $\mathrm{S}_{\mathrm{IV}}{ }^{6+}-\mathrm{P}_{\mathrm{IV}}{ }^{5+}-\mathrm{V}_{\mathrm{IV}}{ }^{5+}-\mathrm{B}_{\mathrm{III}}{ }^{3+}-\mathrm{Si}_{\mathrm{IV}}{ }^{4+}-\mathrm{BIV}^{3+}-$ $\mathrm{Al}_{\mathrm{IV}}{ }^{3+}-\mathrm{Zn}_{\mathrm{IV}}{ }^{2+}$ where the subscript roman numerals indicate the cation coordination. In the presence of a network modifier (e.g. $\mathrm{Na}^{+}$), the closer the ions are in the series, the better is their compatibility for the formation of sulfates and their incorporation in the glass. Thus for instance, sulfate and phosphate tetrahedrons have better compatibility than sulfate and silicate tetrahedrons ${ }^{[6]}$. Therefore, sulfate incorporation into phosphate glasses is higher than sulfate incorporation into silicate glasses.

Sulfur that is not incorporated into the glass system floats to the surface of the glass melt as a separate phase usually containing alkali and alkali earth elements, as well as radioactive elements (gall). This gall is very detrimental as it may sequester radioactive elements ${ }^{[5]}$, and it has a low chemical durability to water; furthermore, the gall can be volatilized forming corrosive off - gases ${ }^{[5,9]}$. The gall can trap gas bubbles in the melt ${ }^{[3,9]}$ and is electrically conductive, which can reduce the efficiency of the furnace ${ }^{[4-6,9]}$, and it is very corrosive to the refractory and furnace 
$[5,6,8,9]$. Another point of consideration is that in experiments conducted while allowing a gall layer to form in continuous feed tests, the glass became super saturated in sulfur. This occurred at $\mathrm{SO}_{4}$ concentrations at or above $0.98 \mathrm{wt} \%{ }^{[9]}$. The super saturation effect of glasses with a gall layer may lead to an overestimation of the sulfur solubility in that specific glass composition.

The volatilization of glass components is a constant factor for any glass melt. In the case of sulfur containing melts, a more reducing atmosphere would lead to higher sulfur volatility, primarily as $\mathrm{SO}_{2}{ }^{[9]}$. This volatilization is thought to be the cause of a 'disappearance' of the gall layer on sulfur rich melts over long periods of time with melts that are exposed to the atmosphere ${ }^{[6]}$. Not only are the long periods of time not feasible for nuclear waste production, the volatilization of the sulfate species could release radioactive elements into the atmosphere. As the diffusion kinetics of sulfur volatilizing from the top of the melt are considerably greater than those of sulfur traveling within the melt, the volatilization of sulfur species from melts without a gall layer can be considered negligible, assuming a melt time in terms of hours ${ }^{[5]}$.

\section{SULFATE THERMODYNAMICS}

Free energy of formation of selected sulfates as a function of temperature is plotted in Figure $1^{[10]}$. The reactions are written for 1 mole of $\mathrm{O}_{2}$ as one of the main reactants. This is relevant to nuclear waste processing as the atmosphere inside the melter is slightly reducing. The most stable form of sulfate is $\mathrm{BaSO}_{4}$ followed by $\mathrm{SrSO}_{4}$.

\section{SULFUR DISOLUTION IN SILICATE GLASS SYSTEMS}

Sulfate is usually found in a silicate network as separate $\mathrm{SO}_{4}{ }^{2-}$ ions or as very small crystallites. $\mathrm{SO}_{4}$ tetrahedra are more disordered and more weakly bonded to surrounding environments than $\mathrm{SO}_{4}$ tetrahedra in sulfate crystals ${ }^{[11]}$. These $\mathrm{SO}_{4}$ tetrahedra can act as nucleation sites for the growth of sulfate crystals within the silicate glass.

\section{a. Additives to Silicate glass systems to increase sulfur solubility}

The addition of alkali and alkaline earth elements have shown promising results in the improvement of sulfur solubility; and other addition such as 
that of transition metals, have also been studied. The molar content of $\mathrm{CaO}$ has been studied for its effects of sulfur dissolution into basaltic melts. $\mathrm{CaO}$ was found to be about 0.3 to 0.28 times as important as $\mathrm{FeO}$ in laboratoryequivalent basaltic melts ${ }^{[7]}$.

In alkali and alkaline earth silicate glass systems, it has been proposed by (Anonymous) that sulfur interacts with the glass network differently based on the sulfur content of the glass. At low $\mathrm{SO}_{4}{ }^{2-}$ content ( $<2 \mathrm{~mol} \%$ ), the sulfite interacts with -Si-O-Si- linkages, and at high $\mathrm{SO}_{4}{ }^{2-}$ content, sulfate interacts with the alkali/alkaline earth cations such as $\mathrm{Ba}^{2+[12]}$.
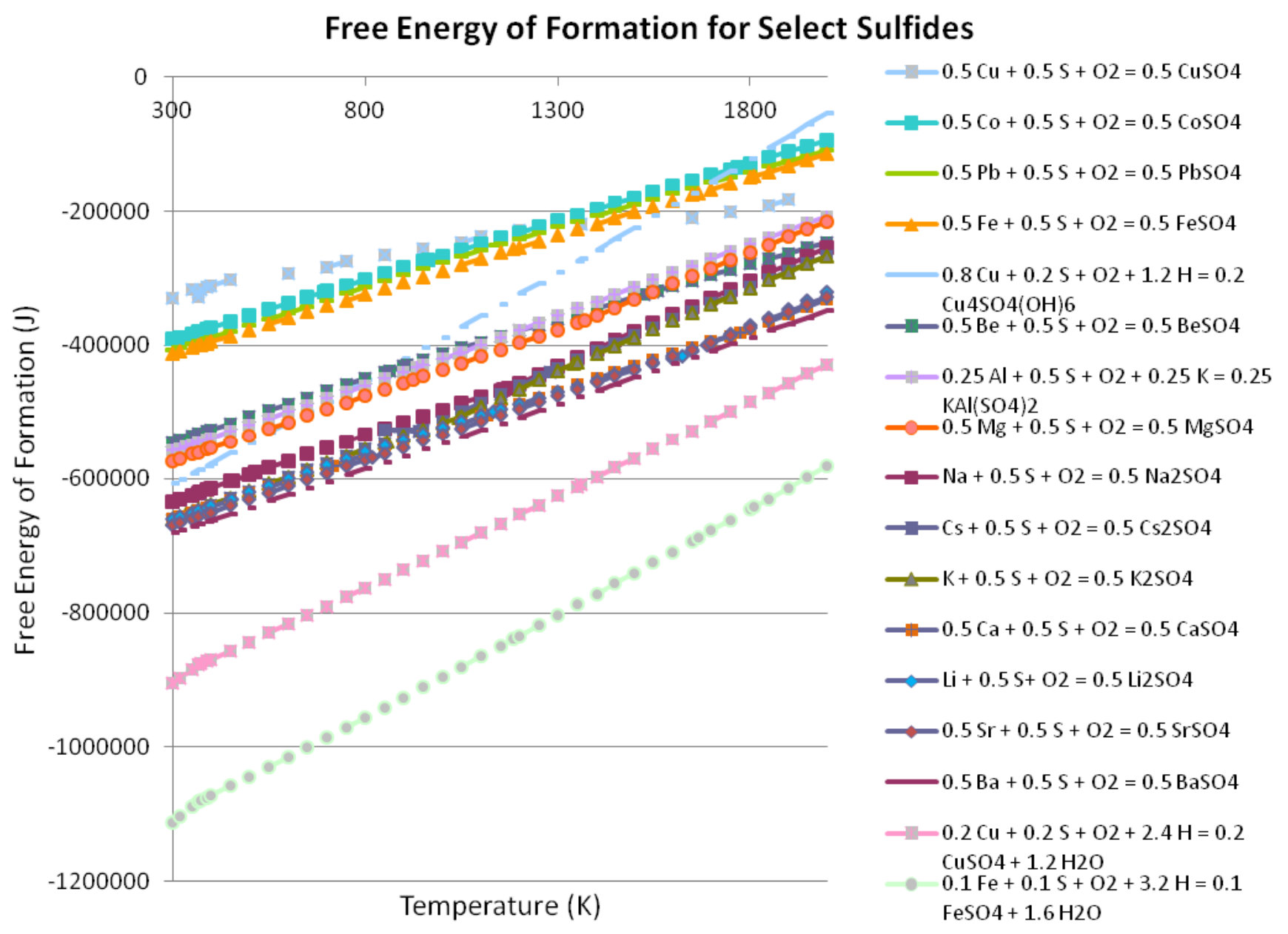

Figure 1. Free Energy of Formation vs. Temperature of Selected Sulfates

\section{SULFUR DISSOLUTION IN PHOSPHATE GLASS SYSTEMS}


Phosphate glasses have previously shown high sulfate solubility, but low chemical durability ${ }^{[6]}$. In a study by Bingham, P.A. et al., sulfate solubility in $60 \mathrm{P}_{2} \mathrm{O}_{5}$ - $40 \mathrm{Fe}_{2} \mathrm{O}_{3}$ is very poor, only 0.01 wt\% $\mathrm{SO}_{3}$ solubility. However, the solubility increases with the addition of other components such as $\mathrm{Na}_{2} \mathrm{O}{ }^{[13]}$. In a more complex phosphate glass system, apatite, minor amounts of $\mathrm{S}$ are present as sulfate substituting for the phosphate group ${ }^{[2]}$.

"When prepared under oxidizing conditions only basic, highly depolymerized phosphate glasses for which $\sum^{\sum\left(\frac{z}{\boldsymbol{a}^{2}}\right)}<\sim 1.2$ : th $>\sim 0.5$; [O] / [P] > 3.8; or $\mathrm{P}_{2} \mathrm{O}_{5}$ content $<\sim 40 \mathrm{~mol} \%$ can incorporate levels of sulfur that could be considered useful from a waste immobilization perspective" [8]

\section{a. Additives to Phosphate glass systems to increase sulfur solubility}

High alkali / alkaline earth phosphate glasses have shown to have high sulfate solubility. One such example is $\mathrm{P}_{2} \mathrm{O}_{5}-\mathrm{CaO}-\mathrm{K}_{2} \mathrm{O}-\mathrm{SO}_{3}$ which has been shown to incorporate $25 \mathrm{~mol}^{\circ} \mathrm{SO}_{3}$, but have poor chemical durability [8].

The addition of iron (Fe) to form a phosphate - iron system has been shown to increase chemical durability, but to have low sulfur solubility. The glass system $60 \mathrm{P}_{2} \mathrm{O}_{5}-40 \mathrm{Fe}_{2} \mathrm{O}_{3}$ has shown to have low sulfur solubility, and multi - component zinc - iron phosphate glass systems are equally low (< $1 \mathrm{~mol} \%)^{[8]}$. Also, for phosphate glasses, the partial pressure of oxygen and of sulfate over the melt can affect the valence state of the sulfur in the melt. Only in a very small region of oxygen partial pressure are both sulfate and sulfide found in a phosphate melt. The oxygen partial pressure region where sulfate and sulfide are both found also coincide with the minimum sulfate solubility limit in the phosphate glasses.

A study was conducted by Bingham and Hand to find whether the addition of alkali or alkaline earth cations would increase the sulfur solubility in the phosphate glass system $60 \mathrm{P}_{2} \mathrm{O}_{5}-40 \mathrm{Fe}_{2} \mathrm{O}_{3}$ and $\mathrm{P}_{2} \mathrm{O}_{5}-\mathrm{Al}_{2} \mathrm{O}_{3}-\mathrm{Na}_{2} \mathrm{O}-$ $\mathrm{Fe}_{2} \mathrm{O}_{3}-\mathrm{SO}_{3}$. The nominal composition $\left[(1-\mathrm{X})\left(0.6 \mathrm{P}_{2} \mathrm{O}_{5}-0.4 \mathrm{Fe}_{2} \mathrm{O}_{3}\right)\right]+\mathrm{XR}_{\mathrm{y}} \mathrm{SO}_{4}$ where $\mathrm{X}$ is between 0 and 0.5 . The nominal composition can incorporate $40-$ 50 mol\% BaO, $30-40$ mol\% $\mathrm{K}_{2} \mathrm{O}$ or $\mathrm{Na}_{2} \mathrm{O}, 20-30$ mol\% $\mathrm{PbO}$, and $10-20$ 
mol\% $\mathrm{Li}_{2} \mathrm{O}, \mathrm{MgO}$, or $\mathrm{CaO}$. This relationship shows that the glass formation region of $60 \mathrm{P}_{2} \mathrm{O}_{5}-40 \mathrm{Fe}_{2} \mathrm{O}_{3}$ increases with an increase in the size of the modifier cation and with the addition of alkali cations verses alkaline earth cations, which is opposite than the trends seen in a binary $\mathrm{P}_{2} \mathrm{O}_{5}-\mathrm{R}_{\mathrm{x}} \mathrm{O}_{\mathrm{y}}$ system. Also, when the atomic fraction of the modifier cation is plotted against the cation field strength of the modifier cation the limits of other alkali and alkaline earth cations can be predicted; it is calculated that the 60P-40Fe glass system can incorporate $\sim 32-34$ mol\% $\mathrm{Rb}_{2} \mathrm{O}, \sim 34-44 \mathrm{~mol} \%$ $\mathrm{Cs}_{2} \mathrm{O}$, and $38-48 \mathrm{~mol} \% \mathrm{SrO}^{[8]}$ The amount of alkali or alkaline earth that the glass is able to incorporate before crystallization could affect the sulfur solubility limit in the glass.

More complex relationships between sulfur solubility in phosphate glass systems have also been observed. It has been noted that $\mathrm{SO}_{3} / \mathrm{mol} \%$ increases with decreasing $\mathrm{P}_{2} \mathrm{O}_{5} / \mathrm{mol} \%$ (b/w $25+70 \mathrm{P}_{2} \mathrm{O}_{5} /$ mol\%), increasing $[\mathrm{O}] /[\mathrm{P}]$ ratio, increasing Theoretical Optical Basicity ( th $)$, and decreasing cation field strength index $\Sigma\left(z / a^{2}\right){ }^{[8]}$.

Overall, in phosphate systems, sulfate incorporation is negligible from a waste immobilization perspective $(<\sim 0.1 \mathrm{~mol} \%)$ in glasses for which $\Sigma\left(\mathrm{z} / \mathrm{a}^{2}\right)$ $>\sim 1.2$; th $<\sim 0.5 ;[\mathrm{O}] /[\mathrm{P}]<\sim 4$; and $\mathrm{P}_{2} \mathrm{O}_{5}<\sim 40 \mathrm{~mol} \%{ }^{\prime \prime}$.

While drawing comparisons between different glass systems such as phosphates and borosilicates 'warrants caution' ${ }^{[8]}$, a linear relationship between molar fraction of basic oxide ( $\mathrm{MgO}, \mathrm{CaO}, \mathrm{FeO}, \mathrm{MnO}$ ) with sulfide capacity of silicate, borosilicate, aluminate and phosphate melts ${ }^{[8]}$ has been observed.

\section{SULFUR DISSOLUTION IN BOROSILICATE GLASS SYSTEMS}

Sulfur dissolution has been studied extensively in borosilicate glass systems. Many of the studies have been focused on the incorporation of high sulfur nuclear waste into the borosilicate glass system used in Trombay, India ${ }^{[3,14,15]}$. As in a silicate glass system, Raman spectroscopy has shown that the sulfate is in the form of sulfate tetrahedrons and it is located at the edge of the glass network, without bonding to the glass network in borosilicate glass systems ${ }^{[16]}$. These sulfate tetrahedra are surrounded with cations such as $\mathrm{Na}^{+}$or $\mathrm{Ca}^{+}{ }^{[11,17]}$, and can act as 
nucleation sites for crystalline sulfates. ${ }^{[1]]}$ This coordination of sulfate tetrahedral incorporated into but not bonded to the glass network can also be seen in aluminosilicate glass systems ${ }^{[2,11]}$.

Different compositions of glasses including different modifiers, different ratios of silica to boron, and different ratios of glass modifier to glass former have shown different sulfur solubility limits. One example is a study of a sodium barium borosilicate glass system which has shown that up to $3 \mathrm{~mol} \%$ of $\mathrm{SO}_{4}{ }^{2-}$ can be loaded within the base glass studied without any phase separation. However, beyond this limit $\mathrm{BaSO}_{4}$ (barite) crystallizes within the matrix ${ }^{[12]}$. Once the solubility limit of any borosilicate is reached, the sulfur tends to form crystals with the alkali and alkaline earth ions within the glass.

White and yellow salt layers formed on the top of saturated borosilicate melts, which were found to be soluble in deionized water. SEM showed that the white coating was highly dendritic and was enriched in sulfur. ICP - AES analysis indicated that the yellow layer was enriched in $\mathrm{Na}$ and $\mathrm{S}^{[9]}$.

\section{a. Additives to Borosilicate glass systems to increase sulfur solubility}

Most studies have shown that to increase sulfur solubility in a borosilicate glass network, the amount of network modifiers needs to be increased, as modifiers such as $\mathrm{Na}, \mathrm{Ca}$ and $\mathrm{Mg}$ can play an important role on diffusion and solubility ${ }^{[5,16]}$. Also, the amount of network formers needs to be reduced so that there is a formation of 'big net cavities' ${ }^{[17]}$ and a depolymerization of the glass network ${ }^{[6]}$. In the case where $\mathrm{Pb}$ was found to have no effect, alkaline earth oxides such as barium oxide $(\mathrm{BaO})$ and calcium oxide $(\mathrm{CaO})$ improved sulfate solubility without phase separation ${ }^{[3]}$. At the Bhabha Atomic Research Center (BARC) in Trombay, a barium based borosilicate glass composition has been developed which reduces the problem of phase separation of sulfate from their nuclear waste ${ }^{[14]}$. Cesium (Cs) additions to borosilicate glass systems have also been compared to $\mathrm{Na}$ additions to borosilicate glass systems. In this study, the incorporation of $\mathrm{X}_{2} \mathrm{SO}_{4}$ seem to be only slightly slower when $\mathrm{X}=\mathrm{Cs}$ than when $\mathrm{X}=\mathrm{Na}$. ${ }^{[6]}$. Another addition to a borosilicate glass system studied is lead $(\mathrm{Pb})$, which has not been shown to improve the sulfate solubility ${ }^{[3]}$. 
While most literature has stated the benefits of the addition of more network modifiers, research has been done to find other alternatives. $\mathrm{V}_{2} \mathrm{O}_{5}$ has been added into borosilicate glass systems, along with the addition of alkali and alkaline earth cations, to observe the effects of $\mathrm{V}_{2} \mathrm{O}_{5}$ on the borosilicate structure, and on the sulfur solubility. $\mathrm{V}_{2} \mathrm{O}_{5}$ was investigated due to the analogies between $\mathrm{V}^{5+}$ ions and $\mathrm{P}^{5+}$ ions since phosphate glasses have traditionally shown higher sulfate solubility. The $\mathrm{V}_{2} \mathrm{O}_{5}$ within the glass structure was found to be in $\mathrm{V}^{5+} \mathrm{O}_{4}$ tetrahedrons, or as $\mathrm{V}^{4+} \mathrm{O}_{5}$ partially disordered sites and it was noted that the amount of $\mathrm{V}^{4+} \mathrm{O}_{5}$ increases relative to the amount of $\mathrm{V}^{5+} \mathrm{O}_{4}$ in a reducing environment. (It is uncertain whether $\mathrm{V}^{4+} \mathrm{O}_{5}$ or $\mathrm{V}^{5+} \mathrm{O}_{4}$ is more desirable) ${ }^{[6]}$. It is believed that the $\mathrm{V}_{2} \mathrm{O}_{5}$ ions may be incorporated into the voids within the borosilicate network, loosening it and allowing it to accept more sulfate ions. The results of this study demonstrate that the addition of $\mathrm{V}_{2} \mathrm{O}_{5}$ does increase the sulfur solubility, but a previous study reports very high levels of sulfur solubility that have not been reproduced) ${ }^{[6]}$. Also in the study that tested the addition of $\mathrm{V}_{2} \mathrm{O}_{5}$ in a borosilicate glass system, when the amount of alkali cations is low, the vanadium oxide was found to act as a modifier and form $\mathrm{VO}_{5}$ square pyramidal units. ${ }^{[6]}$.

As alkali and alkaline earth elements are modifiers in a borosilicate glass system, it is important to understand their effect on the network structure to better understand their effects on glass properties such as chemical durability. One study has shown that when the amount of alkali cations is low, the alkali cations transform 3-coordination borate rings to 4coordination borate tetrahedra, and when the amount of alkali cations is higher all the 3-coordination borate rings are gone, and the alkali cations start to modify the silica and borate network forming $Q^{2}$ and $Q^{3}$ units. Based on this interaction of alkali and alkaline earth elements with the borosilicate glass system and the previously noted interaction of $S$ within the glass network, the addition of $\mathrm{SO}_{4}{ }^{2-}$ may re-polymerize the glass network in the form:

$$
2\left(\mathrm{Si}-\mathrm{O}-\mathrm{X}^{+}\right)+\mathrm{SO}_{4}{ }^{2-} \rightarrow 2(\mathrm{Si}-\mathrm{O}-\mathrm{Si})+\mathrm{X}_{2} \mathrm{SO}_{4}
$$

with $\mathrm{X}$ representing an alkali element ${ }^{[6]}$. 
Another study by Mishra showed that: with increased $\mathrm{SO}_{4}{ }^{2-}$ from 0 to 2 mol\% the ratio of $\mathrm{Q}^{2}: \mathrm{Q}^{3}$ changed from 59:41 to 62:38; there was no change with higher $\mathrm{SO}_{4}{ }^{2-}$. From 0 to 2 mol\% $\mathrm{SO}_{4}{ }^{2-},\left[\mathrm{BO}_{4}\right]:\left[\mathrm{BO}_{3}\right]$ remained unchanged at 38:62. Therefore, this study showed that at low $(<2)$ mol\%, $\mathrm{SO}_{4}{ }^{2-}$ interacts with $\mathrm{O}-\mathrm{Si}-\mathrm{O}$ bonds, but at higher $(>2) \mathrm{mol}^{2}, \mathrm{SO}_{4}{ }^{2-}$ interacts with cations ${\text { (like } \mathrm{Ba}^{2+} \text { ions) }}^{[15]}$.

"Phase separation studies on the samples revealed that as much as 3 mol\% of $\mathrm{SO}_{4}{ }^{2-}$ can be loaded within the base glass without any phase separation" (Beyond this, $\mathrm{BaSO}_{4}$ crystallizes within the matrix) $^{[15]}$.

At high oxidation states, only $\mathrm{SO}_{4}{ }^{2-}$ is dissolved in the melt and sulfur diffusion is one to two orders of magnitude lower than in a reducing atmosphere. ${ }^{[5]}$

Tables 1 and 2 and Figure 2 include various borosilicate glass compositions. Figure 2 ranks these glass compositions based on their sulfur content within the glass. Some publications related sulfur content in terms of sulfide $\left(\mathrm{SO}_{2}\right)$ and some in terms of sulfite $\left(\mathrm{SO}_{3}\right)$. The glass compositions are listed in order of their sulfur content in Tables 1 and 2. Table 2 just lists the components of the glass systems while Table 2 also lists their network former content, network modifier content, and the ratios of former to modifier. The relative lack in relationship between sulfur content and glass former to modifier ratio is assumed to be caused by the large variety of network modifiers used by various studies; however, some conclusions may be drawn; one example would be that the addition of Vanadium (V) may increase the sulfate solubility. 
Table 1. Various Compositions of Borosilicate Glass Systems.

\begin{tabular}{|l|l|l|l|l|l|l|l|l|l|l|l|l|l|}
\hline $\begin{array}{l}\text { Composition } \\
\text { Name }\end{array}$ & $\mathrm{SiO}_{2}$ & $\mathrm{~B}_{2} \mathrm{O}_{3}$ & $\mathrm{Al}_{2} \mathrm{O}_{3}$ & $\mathrm{Na}_{2} \mathrm{O}$ & $\mathrm{BaO}$ & $\mathrm{Li}_{2} \mathrm{O}$ & $\mathrm{CaO}$ & $\mathrm{Fe}_{2} \mathrm{O}_{3}$ & $\mathrm{SO}_{3}$ & $\mathrm{SO}_{4}$ & $\mathrm{Na}_{2} \mathrm{SO}_{4}$ & $\mathrm{CsSO}_{4}$ & $\mathrm{~V}_{2} \mathrm{O}_{5}$ \\
\hline $\begin{array}{l}\text { SBNa47-30- } \\
\text { NaS }\end{array}$ & 51.81 & 20.57 & & 28.21 & & & & & 1.49 & & & & \\
\hline ANaV & 45 & 14.4 & 6.3 & 14.4 & & & 4.5 & 5.4 & 0.9 & & 5 & & 5 \\
\hline SB44C & 28.18 & 18.48 & & 8.78 & 17.56 & & & & & 0.891 & 1.3179 & & \\
\hline SB44B & 28.96 & 18.9 & & 9.02 & 18.04 & & & & & 0.825 & 1.2203 & & \\
\hline 702 & 76 & 8 & & 6 & & 10 & & & & 0.8 & & & \\
\hline SB44A & 29.73 & 19.49 & & 9.26 & 18.52 & & & & & 0.759 & 1.1226 & & \\
\hline Ana & 47.5 & 15.2 & 6.65 & 15.2 & & & 4.75 & 5.7 & 0.7 & & 5 & & \\
\hline SB44 & 30.5 & 20 & & 9.5 & 19 & & & & & 0.693 & 1.025 & & \\
\hline $\begin{array}{l}\text { SBBa22-33- } \\
\text { BaS }\end{array}$ & 13.23 & 30.86 & & & 55 & & & & 0.69 & & & & \\
\hline 418 & 76 & 8 & & 8 & & 8 & & & & 0.6 & & & \\
\hline $\begin{array}{l}\text { SBNa53-20- } \\
\text { NaS }\end{array}$ & 50.58 & 27.74 & & 21.12 & & & & & 0.56 & & & & \\
\hline ACs & 43.63 & 13.96 & 6.11 & 13.96 & & & 4.36 & 5.24 & 0.55 & & & 12.74 & \\
\hline
\end{tabular}

Table 2. Ratio of Network Formers to Network Modifiers.

\begin{tabular}{|l|c|c|c|c|}
\hline $\begin{array}{l}\text { Composition } \\
\text { Name }\end{array}$ & $\begin{array}{c}\text { Glass } \\
\text { Formers }\end{array}$ & $\begin{array}{c}\text { Glass } \\
\text { Modifiers }\end{array}$ & $\begin{array}{c}\text { Glass Formers / } \\
\text { Glass Modifiers }\end{array}$ & $\begin{array}{c}\text { Rank } \\
\text { (high to low) }\end{array}$ \\
\hline SBNa47-30-NaS & 72.38 & 28.21 & 2.5658 & 7 \\
\hline ANaV & 65.7 & 24.3 & 2.7 & 6 \\
\hline SB44C & 46.66 & 26.34 & 1.7715 & 9 \\
\hline SB44B & 47.86 & 27.06 & 1.7687 & 11 \\
\hline 702 & 84 & 16 & 5.25 & 2 \\
\hline SB44A & 49.22 & 27.78 & 1.7718 & 8 \\
\hline ANa & 69.35 & 25.65 & 2.7037 & 5 \\
\hline SB44 & 50.5 & 28.5 & 1.77 & 10 \\
\hline SBBa22-33-BaS & 44.09 & 55 & 0.8 & 12 \\
\hline
\end{tabular}


SRNL-STI-2011-00524

Revision 0

\begin{tabular}{|l|c|c|c|c|}
\hline 418 & 84 & 16 & 5.25 & 1 \\
\hline SBNa53-20-NaS & 78.32 & 21.12 & 3.3243 & 3 \\
\hline ACs & 63.7 & 23.56 & 2.704 & 4 \\
\hline
\end{tabular}




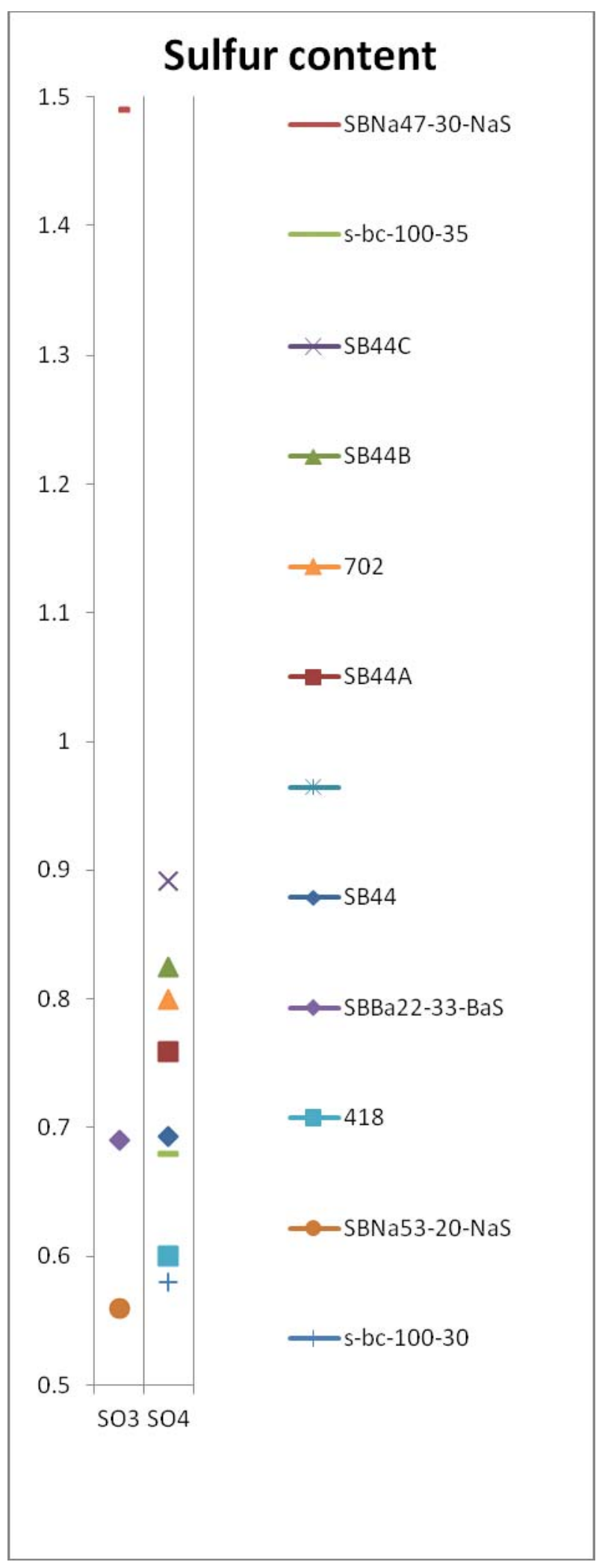

Figure 2. Sulfur Contents of Various Borosilicate Glass Systems 


\section{OTHER GLASS SYSTEMS}

Sulfur in aluminosilicate glass systems has also been found to be incorporated as sulfate tetrahedrons that are not bonded to the glass network. In fluoroaluminate glasses where $\mathrm{BaF}_{2}$ was substituted by $\mathrm{BaSO}_{4}$, the chemical durability of the glass has been found to be greatly reduced ${ }^{[18]}$. In laboratory - equilibrated basaltic melts, the molar content of $\mathrm{CaO}$ makes a significant contribution to the $\mathrm{S}$ capacity ${ }^{[2]}$.

One study also showed that the redox conditions of the melt may affect which cations are surrounding a sulfate tetrahedron. Lazurite $\left[\mathrm{Na}_{6} \mathrm{Ca}_{2} \mathrm{Al}_{6} \mathrm{Si}_{6} \mathrm{O}_{24}\left(\mathrm{SO}_{4}, \mathrm{~S}\right)_{2}\right]$ (predominantly reduced species) and Haüyne $\left[\mathrm{Na}_{6} \mathrm{Ca}_{2} \mathrm{Al}_{6} \mathrm{Si}_{6} \mathrm{O}_{24}\left(\mathrm{SO}_{4}\right)_{2}\right]$ (predominantly oxidized species) accommodate various species of sulfur within the interstices of an aluminosilicate framework. In Lazurite, XANES shows S bonded only to $\mathrm{Na}$; in Haüyne, a sharp peak at $2481.7 \mathrm{eV}$ is "consistent with sulfate bonded to $\mathrm{Ca}$ and $\mathrm{Na}^{\text {" [2] }}$.

\section{LABORATORY TESTS TO DETECT SULFUR LEVELS}

Sulfate impurities induced a strong optical absorption band between 8 and $9 \mu \mathrm{m}$ [19].

\section{a. Raman Spectroscopy}

Many studies have used Raman spectroscopy to test the sulfur dissolution within a glass system. Raman spectroscopy can be used with low concentrations of sulfur, and Raman spectra have shown that sulfur in most glass systems is comparable to $\mathrm{S}^{6+}$ in crystals ${ }^{[11]}$. It has also been seen that there is a peak shift in borosilicate glass systems containing potassium (K), Sodium (Na), or $\mathrm{Na}$ and Calcium (Ca) from 980 to $995 \mathrm{~cm}^{-1}[11]$.

Peaks of interest in glass systems are summarized here:

- Between 200 and $850 \mathrm{~cm}^{-1}$ represents the bending of Si-O-Si ${ }^{[4]}$

- Between 230 and $500 \mathrm{~cm}^{-1}$ represents a S-S bond ${ }^{[11]}$

- Near $300 \mathrm{~cm}^{-1}$ represents the $\mathrm{S}-\mathrm{S}$ stretch of $\mathrm{S}_{2} \mathrm{O}_{6}{ }^{2-[11]}$ 
- Between 350 and $600 \mathrm{~cm}^{-1}$ is due to vibrations of trigonal $\mathrm{VO}_{5}$ bipyramids and the silica network (when $\mathrm{V}$ is present) ${ }^{[6]}$

- Near $460 \mathrm{~cm}^{-1}$ is the symmetric O-S-O bend which is also found in crystalline sulfates $^{[4]} \cdot\left(v_{2}\right)^{[11]}$

- Near $500 \mathrm{~cm}^{-1}$ is assigned to silica units ${ }^{[6]}$

- From 550 to $850 \mathrm{~cm}^{-1}$ represents borate vibrations and ring breathing ${ }^{[4]}$

- Around 580 and $630 \mathrm{~cm}^{-1}$ represents the breathing modes of borate rings ${ }^{\text {[4] }}$

- Near $620 \mathrm{~cm}^{-1}$ represents an asymmetric O-S-O bend which is also found in crystalline sulfates) ${ }^{[4]}$

- Near $630 \mathrm{~cm}^{-1}$ is a sulfur dependent mode ${ }^{[11]}$ (danburite rings breathing ${ }^{[6]}$ )

- Near $640 \mathrm{~cm}^{-1}$ is an asymmetric O-S-O bending mode $\left(\mathrm{v}_{4}\right)^{[11]}\left(\mathrm{O}-\mathrm{S}-\mathrm{O}\right.$ stretch $\mathrm{v}_{4}$ ${ }^{[6]}$ )

- Around $770 \mathrm{~cm}^{-1}$ represents 4-fold coordination boron ${ }^{[4,6]}$

- Around $803 \mathrm{~cm}^{-1}$ represents 3-fold coordination boron ${ }^{[4,6]}$

- Around 850 and $910 \mathrm{~cm}^{-1}$ is a reference $\mathrm{VO}_{5}{ }^{[6]}$

- Between 850 and $1250 \mathrm{~cm}^{-1}$ represents Si-O stretching (centered near 950, 1050,1100 , and $\left.1150 \mathrm{~cm}^{-1}\right)^{[4]}$

- Around $895 \mathrm{~cm}^{-1}$ is a reference to $\mathrm{VO}_{4}\left(\mathrm{VO}_{4}\right.$ tend not to form in low-alkali glasses borosilicate glasses ${ }^{[6]}$ )

- Between 950 and $980 \mathrm{~cm}^{-1}$ represents $Q^{2}$ units ${ }^{[4]}$ (line around $950 \mathrm{~cm}^{-1}$ represents $\mathrm{Q}^{2} \mathrm{Si}^{-} \mathrm{O}^{-} \mathrm{Na}^{+}$stretch ${ }^{[6]}$ )

- Line at $960 \mathrm{~cm}^{-1}$ could correspond to boron units with one NBO (with vanadium containing samples ${ }^{[6]}$

- Near 970 and $990 \mathrm{~cm}^{-1}$ represents $\mathrm{S}^{4+}\left(\mathrm{SO}_{3}{ }^{2-}\right)\left(\mathrm{S}-\mathrm{O}\right.$ stretch) ${ }^{[11]}$

- A sharp line between 975 and $990 \mathrm{~cm}^{-1}$ represents $v_{1}$ (S-O stretch) ${ }^{[6]}$

- A narrow peak near $990 \mathrm{~cm}^{-1}$ can suggest sulfate presence and peak intensity can indicate sulfur content after deconvolution ${ }^{[4]}$, a sulfur dependent mode [11]

- Near $1000 \mathrm{~cm}^{-1}$ represents a symmetric S-O stretch ${ }^{[4]}$ from tetrahedral $\mathrm{SO}_{4}$ $\left(v_{1}\right)^{[11]}$

- Between 1000 and $1050 \mathrm{~cm}^{-1}$ represents an alkali cation ${ }^{[4]}$

- Centered between 1050 and $1100 \mathrm{~cm}^{-1}$ represents $\mathrm{Si}^{-O^{-}}\left(\mathrm{Q}^{3}\right){ }^{[4]}$ (line around $1075 \mathrm{~cm}^{-1} \mathrm{Q}^{3} \mathrm{Si}^{-} \mathrm{O}^{-} \mathrm{Na}^{+}$stretch ${ }^{[6]}$ )

- Near $1100 \mathrm{~cm}^{-1}$ represents an asymmetric S-O stretch ${ }^{[4]}\left(v_{3}\right)^{[6,11]}$

- Between 1120 and $1190 \mathrm{~cm}^{-1}$ represents fully polymerized $Q^{4}{ }^{[4]}$ (line around $1120 \mathrm{~cm}^{-1} \mathrm{Q}^{4} \mathrm{Si}-\mathrm{O}$ stretch ${ }^{[6]}$ )

- Between 1250 and $1600 \mathrm{~cm}^{-1}$ represents $\mathrm{B}^{-} \mathrm{O}^{-}$stretching ${ }^{[4]}$ 
- A broad band between $1400-1500 \mathrm{~cm}^{-1}$ represents a $\mathrm{B}^{-} \mathrm{O}^{-}$stretch in chaintype metaborate groups ${ }^{[6]}$

- Around $1410 \mathrm{~cm}^{-1}$ represents $\mathrm{BO}_{2} \mathrm{O}^{-}$triangles linked to $\mathrm{BO}_{4}{ }^{-}$units ${ }^{[4]}$

- Around $1500 \mathrm{~cm}^{-1}$ represents $\mathrm{BO}_{2} \mathrm{O}^{-}$triangles linked to other $\mathrm{BO}_{3}$ units ${ }^{[4]}$

- $\mathrm{v}_{1}$ and $\mathrm{v}_{4}$ correlate to sulfate crystals. $\mathrm{v}_{1}$ shifts with different cation (radius and polarization) ${ }^{[11]}$.

To determine sulfate levels as a function of depth, Raman spectra can be taken of cross - sections parallel to the surface of the glass (as a function of depth) ${ }^{[20]}$.

\section{b. Infrared Spectroscopy}

Infrared bands between 1050 and $1200 \mathrm{~cm}^{-1}$ correspond to the $v_{3}$ vibration of the $\mathrm{SO}_{4}$ ion. A weaker band just below $1000 \mathrm{~cm}^{-1}$ corresponds to the $v_{1}$ vibration. The two peaks at 600 and $650 \mathrm{~cm}^{-1}$ correspond to the $v_{4}$ vibration ${ }^{[21]}$.

\section{c. X-ray absorption - near edge spectroscopy (XANES)}

X-ray absorption near edge spectroscopy (XANES) can be used as a nondestructive technique for characterizing and quantifying $S$ species in compositionally complex materials such as silicate glass ${ }^{[2]}$. XANES can be used to find the sulfur valence and its surrounding environment. Edge positions progressively shift to higher energies as sulfur valence increases from $S_{2}{ }^{2-}$ to $S^{4+}$ to $S^{6+[11]}$. Also, there is a shift from the reduced species at $2473-2474 \mathrm{eV}$ (sulfide, disulfide, thiol, and thiophene), to the intermediate species at $2474-2475 \mathrm{eV}$ (sulfoxide) and $2480-2481 \mathrm{eV}$ (sulfonate), and to the oxidized species at $2482 \mathrm{eV}$ (sulfate) ${ }^{[2]}$. There is an overall shift of about $45 \mathrm{eV}$ in the positions of $\mathrm{K}$ - and L- edge peaks for metal sulfides which correlate linearly with increase in the direct energy - band gap ${ }^{[2]}$. While both $\mathrm{S} \mathrm{K}$ - and $\mathrm{L}$ - edge XANES spectra are sensitive to $\mathrm{S}$ functional groups, the $S L-$ edge method is more sensitive to $S$ functional groups ${ }^{[2]}$.

Weak shoulder in basaltic glasses at $2470-2471 \mathrm{eV}$ represents Fe monosulfides dissolved in glasses and melts ${ }^{[2]}$. 
Feature near $2475 \mathrm{eV}$ is consistent with isolated $\mathrm{SCa}_{\mathrm{n}}$ in the melt ${ }^{[2,7]}$. (S occurs as isolated $\mathrm{SCa}_{\mathrm{n}}$ coordination polyhedra in the sodium aluminosilicate glass ${ }^{[2]}$.)

Sulfur edges near $2481 \mathrm{eV}$ indicating $\mathrm{SO}_{4}{ }^{[11]}$.

Signature sulfate peak at $2482 \mathrm{eV}^{\text {[7] }}$ (2482eV corresponds to k-edge of sulfate ${ }^{[2]}$ )

\section{d. Extended X - ray absorption - fine structure (EXAFS)}

Sulfate species can also be detected with EXAFS with the use of crystalline sulfates as standards. The Fourier transform of a broad peak at $3.4 \AA$ in the EXANES of $\mathrm{Na}_{2} \mathrm{SO}_{4}$ is due to ten $\mathrm{Na}$ atoms at $3.112 \AA$, $3.444 \AA$, and $3.470 \AA$, and four $\mathrm{O}$ atoms at $3.595 \AA .{ }^{[16]}$

\section{e. Other tests}

Visual observations can act as a reference to determine if more sophisticated tests are required. SEM/EDS is useful to characterize the surface of glass melts and to characterize any unique features that are observed. ${ }^{[9]}$. XRD is useful in confirmation of any crystallization phases formed.

Bond valence is a useful way to predict the bonding environment of sulfur tetrahedrons. If it is assumed that any oxygen linked to the central $\mathrm{S}^{6+}$ cation must receive an additional $0.5 \mathrm{vu}$, then we can understand why a $\mathrm{SO}_{4}$ tetrahedra will not bond to $\mathrm{PO}_{4}, \mathrm{AsO}_{4}, \mathrm{VO}_{4}, \mathrm{SiO}_{4}$ or $\mathrm{AlO}_{4}$ because the ideal valence sums would greatly exceed $2 .{ }^{[21]}$

\section{STRATEGY DEVELOPMENT}

Based on literature survey results and detailed discussions with client (Savannah River National Laboratory), three different strategies have been selected. These strategies are briefly discussed in this section.

\section{a. First Strategy}

This approach consists of simple addition of Barium to a basic frit with specific waste loading. Two basic frit choices are: frit 418 (being used now in 
SRNL-STI-2011-00524

Revision 0

the vitrification plant), but frit 702 has shown a higher sulfate solubility. The only difference between the 2 frits is alkali cation type/content $(418 \rightarrow$ $76 \mathrm{wt} \% \mathrm{SiO}_{2}, 8 \mathrm{wt} \% \mathrm{~B}_{2} \mathrm{O}_{3}, 8 \mathrm{wt} \% \mathrm{Na}_{2} \mathrm{O}, 8 \mathrm{wt} \% \mathrm{Li}_{2} \mathrm{O} ; 702 \rightarrow 76 \mathrm{wt} \% \mathrm{SiO}_{2}, 8 \mathrm{wt} \%$ $\mathrm{B}_{2} \mathrm{O}_{3}, 6 \mathrm{wt} \% \mathrm{Na}_{2} \mathrm{O}, 10 \mathrm{wt} \% \mathrm{Li}_{2} \mathrm{O}$ ). Barium addition to increase sulfur solubility will be normalized to $100 \mathrm{wt} \%$.

\section{b. Second Strategy}

This approach consists of addition of Vanadium Oxide, which has been reported to increase sulfate solubility in glass. This is expected to impact the redox equilibrium of the glass significantly. This addition can be balanced by adjusting Iron oxide content in the glass comparison.

\section{c. Third Strategy}

The third strategy is adjust $\mathrm{Ca}: \mathrm{Ba}: \mathrm{Sr}$ to reduce crystallization and to increase sulfate solubility.

Additionally, along with these strategies, a fining agents, e.g., Pb, As, Se, or $\mathrm{F}$ will also be studied to decrease the viscosity of the melt.

\section{EXPERIMENTAL PLAN}

Detailed experimental plan will be developed and implemented in September 2011. Effect of three different additives $\left(\mathrm{BaO}, \mathrm{PbO}\right.$, and $\left.\mathrm{V}_{2} \mathrm{O}_{5}\right)$ at concentrations over 1-10 weight $\%$ on sulfate retention and waste form performance will be investigated.

\section{REFERENCES}

1. Billings, Amanda L. and Fox, Kevin M., "Retention of Sulfate in Savannah River Site High-Level Radioactive Waste Glass," International Journal of Applied Glass Science, 1 [4] 388-400 (2010).

2. $\quad$ Fleet, Michael E., "XANES Spectroscopy of Sulfur in Earth Materials," The Canadian Mineralogist, 43 [6] 1811-38 (2005). 
3. Kaushik, C., Mishra, R., Sengupta, P., Kumar, A., Das, D., Kale, G. and Raj, K., "Barium borosilicate glass - a potential matrix for immobilization of sulfate bearing high-level radioactive liquid waste," Journal of Nuclear Materials, 358 [2-3] 129-38 (2006).

4. Lenoir, M., Grandjean, A., Poissonnet, S. and Neuville, D. R., "Quantitation of sulfate solubility in borosilicate glasses using Raman spectroscopy," Journal of Non-Crystalline Solids, 355 [28-30] 1468-73 (2009).

5. Lenoir, Marion, Neuville, Daniel R., Malki, Mohammed and Grandjean, Agnès, "Volatilization kinetics of sulphur from borosilicate melts: A correlation between sulphur diffusion and melt viscosity," Journal of Non-Crystalline Solids, 356 [50-51] 2722-7 (2010).

6. Manara, D., Grandjean, A., Pinet, O., Dussossoy, J. and Neuville, D., "Sulfur behavior in silicate glasses and melts: Implications for sulfate incorporation in nuclear waste glasses as a function of alkali cation and $\mathrm{V}_{2} \mathrm{O}_{5}$ content," Journal of Non-Crystalline Solids, 353 [1] 12-23 (2007).

7. Michael E. Fleet, Xiaoyang Liu, Sarah L. Harmer, and Penelope L. King, "Sulfur K-Edge XANES Spectroscopy: Chemical State and Content of Sulfur in Silicate Glasses," The Canadian Mineralogist, 43 [5] 1605-3 (2005).

8. Bingham, P. A. and Hand, R. J., "Sulphate incorporation and glass formation in phosphate systems for nuclear and toxic waste immobilization," 43 [7] 1679-93 (2008).

9. Peeler, D.K. , Herman, C.C. , Smith, M.E. , Lorier, T.H. , Best, D.R. , Edwards, T.B. and Baich, M.A. , "An Assessment of the Sulfate Solubility Limit for the Frit 418 - Sludge Batch 2/3 System," Savannah River Technology Center, 1-78 (2004). 
10. "FACTSAGE (Not sure how to site),"

11. McKeown, David A., Muller, Isabelle S., Gan, Hao, Pegg, Ian L. and Kendziora, Christopher A., "Raman studies of sulfur in borosilicate waste glasses: sulfate environments," Journal of Non-Crystalline Solids, 288 [1-3] 191-9 (2001).

12. Anonymous, "Ceramics; Research from R.K. Mishra et al broadens understanding of ceramics," Technology Business Journal, 582 (2009).

13. Bingham, P. A., Hand, R. J., Forder, S. D., Lavaysierre, A., Kilcoyne, S. H. and Yasin, I., "Preliminary studies of sulphate solubility and redox in 60P2O5-40Fe2O3 glasses," Materials Letters, 60 [6] 844-7 (2006).

14. Mohapatra, M., Kadam, R. M., Mishra, R. K., Dutta, D., Pujari, P. K., Kaushik, C. P., Kshirsagar, R. J., Tomar, B. S. and Godbole, S. V., "Electron beam irradiation effects in Trombay nuclear waste glass," Nuclear Instruments and Methods in Physics Research Section B: Beam Interactions with Materials and Atoms, In Press, Accepted Manuscript 1-21 (2011).

15. Mishra, Raman K., Sudarsan, Kumaran V., Sengupta, Pranesh, Vatsa, Rajesh K., Tyagi, Avesh K., Kaushik, Chetan P., Das, Dasarathi and Raj, Kanwar, "Role of Sulfate in Structural Modifications of Sodium Barium Borosilicate Glasses Developed for Nuclear Waste Immobilization," J Am Ceram Soc, 91 [12] 3903-7 (2008).

16. Brendebach, B., Denecke, M. A., Roth, G. and Weisenburger, S., "Sulfur incorporation in high level nuclear waste glass: A S K-edge XAFS investigation," Journal of Physics: Conference Series, 190012186 (2009). 
17. Liu, Li-Jun, Zhou, Hui, Qie, Dong-Sheng, Li, Jin-Ying, Li, Bao-Jun, Xu, Jian-Hua, Li, Yang and Jiang, Yao-Zhong, "Raman spectroscopy of sulfur structure in borosilicate waste glasses," Atomic Energy Science and Technology, 43 [2] 103-7 (2009).

18. Saad, Mohammed, Farissi, Mohamed El and Poulain, Marcel, "Influence of sulphate anions on the chemical durability of the BATY glass," Journal of Non-Crystalline Solids, 140 112-8 (1992).

19. Messaddeq, Y. and Poulain, M., "Influence of sulphate impurities on the IR transmission of InF3-based glasses," Journal of Non-Crystalline Solids, 140 77-81 (1992).

20. Konijnendijk, W. L. and Buster, J. H. J. M., "Raman-scattering measurements of silicate glasses containing sulphate," 23 [3] 401-18 (1977).

21. Wylde, Jonathan J., Allen, Geoffrey C. and Collins, Ian R., "FT-IR and Raman Spectroscopic Characterization of the Major Oilfield Sulfate Scale Forming Minerals," Applied Spectroscopy, 55 [9] 1155-60 (2001). 


\section{Distribution:}

J. W. Amoroso, 999-W

A. B. Barnes, 999-W

D. A. Crowley, 773-43A

A. P. Fellinger, 773-41A

S. D. Fink, 773-A

K. M. Fox, 999-W

B. J. Giddings, 786-5A

C. C. Herman, 999-W

F. C. Johnson, 999-W

S. L. Marra, 773-A

D. J. McCabe, 773-42A

A. M. Murray, 773-A

D. K. Peeler, 999-W

F. M. Pennebaker, 773-42A

W. R. Wilmarth, 773-A 